\title{
Removal of Phenol from Synthetic and Industrial Wastewater by Potato Pulp Peroxidases
}

\author{
Katarzyna Kurnik • Krzysztof Treder • \\ Monika Skorupa-Klaput • Andrzej Tretyn • \\ Jarosław Tyburski
}

Received: 24 March 2015 / Accepted: 23 June 2015 / Published online: 11 July 2015

(C) The Author(s) 2015. This article is published with open access at Springerlink.com

\begin{abstract}
Plant peroxidases have strong potential utility for decontamination of phenol-polluted wastewater. However, large-scale use of these enzymes for phenol depollution requires a source of cheap, abundant, and easily accessible peroxidase-containing material. In this study, we show that potato pulp, a waste product of the starch industry, contains large amounts of active peroxidases. We demonstrate that potato pulp may serve as a tool for peroxidase-based remediation of phenol pollution. The phenol removal efficiency of potato pulp was over $95 \%$ for optimized phenol concentrations. The potato pulp enzymes maintained their activity at $\mathrm{pH} 4$ to 8 and were stable over a wide temperature range. Phenol solutions treated with potato pulp showed a significant reduction in toxicity compared with untreated phenol solutions. Finally we determined that this method may be employed to remove phenol from industrial effluent with over $90 \%$ removal efficiency under optimal conditions.
\end{abstract}

K. Kurnik • M. Skorupa-Kłaput • A. Tretyn · J. Tyburski $(\bowtie)$ Chair of Plant Physiology and Biotechnology, Nicolaus Copernicus University, Lwowska 1, 87-100 Toruń, Poland e-mail: tybr@umk.pl

\section{K. Treder}

Laboratory of Molecular Diagnostic and Biochemistry, Department of Potato Protection and Seed Science in Bonin, Plant Breeding and Acclimatization Institute-National Research Institute, 76-009 Bonin, Poland

A. Tretyn · J. Tyburski

Centre for Modern Interdisciplinary Technologies, Nicolaus Copernicus University, Wileńska 4, 87-100 Toruń, Poland
Keywords Bioremediation · Peroxidase isoenzymes . Phenol $\cdot$ Potato pulp $\cdot$ Wastewater treatment

\section{Introduction}

Phenol and its derivatives are major organic pollutants, produced by various industrial activities, such as coal conversion, petroleum refining, resin, plastic and pharmaceutical production, wood preservation, metal coating, and textile dyeing (Michałowicz and Duda 2007; Hamid and Rehman 2009; Varsha et al. 2011). Moreover, pesticide production and degradation release huge quantities of phenols into the environment (Michałowicz and Duda 2007).

Exposure to most phenolic compounds poses a serious risk to human health, due to their toxic, mutagenic, carcinogenic, and teratogenic effects (Michałowicz and Duda 2007). Therefore, phenolic compounds need to be eliminated from wastewater before the water is discharged into the environment (Hamid and Rehman 2009). Conventional, physico-chemical methods for phenol removal from industrial wastewaters include membrane filtration; coagulation/flocculation; ion exchange; electrolysis, adsorption on activated carbon; advanced oxidation processes (chlorination, bleaching, ozonation, Fenton oxidation, photocatalytic oxidation); and chemical reduction. All these methods suffer from serious shortcomings due to limited effectiveness and high operational costs (Radushev et al. 2008; Qayyum et al. 2009). Thus, considerable work has aimed to develop alternative methods for the removal of phenolic 
pollutants from industrial waste streams and the environment. Biodegradation has emerged as one of the most promising approaches for processing water contaminated with phenols. Several reports show partial or complete biodegradation of such chemicals by cultures of bacteria, fungi, or algae (Aitken et al. 1989; Longoria et al. 2008). However, using microbes for treating pollutants is still an expensive process, due to the high costs of producing the microbial culture. Moreover, inhibitors present in the effluent may suppress growth of the culture and the expression of enzymes involved in the degradation of phenolic compounds may vary over time, or depend on the growth phase of the organism (Qayyum et al. 2009).

Enzymatic treatment with peroxidase has been proposed as another strategy for the remediation of phenolcontaminated wastewater. Peroxidases catalyze the oxidative transformation of a variety of organic and inorganic compounds at the expense of peroxide, usually $\mathrm{H}_{2} \mathrm{O}_{2}$. Peroxidases oxidize phenolic compounds to highly reactive radical species, which spontaneously produce insoluble oligo- or polymeric derivatives. These insoluble, polymerized products may be removed from solutions by simple filtration or sedimentation techniques (Regalado et al. 2004). Peroxidases that have been used for treatment of phenolic contaminants include fungal class II peroxidases, such as lignin peroxidase (LiP) or manganese peroxidase (MnP), or plant class III peroxidases, including horseradish peroxidase (HRP), soybean peroxidase, turnip peroxidase (Regalado et al. 2004), or bitter gourd peroxidase (Ashraf and Husain 2010). Among class III peroxidases, HRP has been most commonly used for studies of phenol removal. However, the high cost of purified HRP and its high susceptibility to inactivation by various side reactions during treatment diminish the usefulness of HRP for large-scale bioremediation (González et al. 2008). Soybean peroxidase, considered as an alternative to HRP, is cheaper than HRP, and displays some favorable characteristics, such as higher thermotolerance and higher conformational stability over a wide $\mathrm{pH}$ range. However, like HRP, soybean peroxidase is still quite susceptible to inactivation during phenol oxidation and polymerization (Feng et al. 2013).

Besides the preparations of purified enzyme (immobilized or free), several peroxidase-producing systems have been considered for use in phenol remediation. Hairy root cultures have been tested for their ability to remove phenol or dichlorophenol (González et al. 2006, 2008, 2012; Singh et al. 2006; Paisio et al. 2010; Sosa Alderete et al. 2012; Jha et al. 2013). Hairy roots offer an attractive system for this purpose due to their ability to produce large quantities of exudates that are rich in peroxidase and chelating agents. Moreover, hairy roots have fast rates of biomass production, providing an extensive area of contact with contaminated solution (Suza et al. 2008). Most studies on phenol remediation by hairy roots have been conducted on a laboratory scale. However, recent work has successfully scaled up the removal of 2,4-dichlorophenol using Brassica napus hairy roots in stirred tank reactor, thus opening future prospects for employing hairy roots on an industrial-scale for biodepollution of wastewater (Angelini et al. 2011).

Besides hairy root cultures, some other sources of peroxidase have been considered for utilization in wastewater decontamination. Crude enzyme extracts from Raphanus sativus roots efficiently remove phenolic compounds from wastewater from the leather industry (Diao et al. 2011). Juice from cut roots of Raphanus was also able to decontaminate phenolpolluted synthetic wastewater (Naghibi et al. 2003). The peroxidase-containing homogenate from onion solid waste, obtained after peeling the bulbs, was examined for its ability to oxidize caffeic acid, the main contaminant in wastewater from olive mills (El Agha et al. 2008). Minced shepherd's purse (Capsella bursa-pastoris) roots were used for the remediation of soil contaminated with 2,4-dichlorophenol (Park et al. 2006).

One prerequisite for the large-scale application of plant peroxidases for bioremediation is the availability of large quantities of cheap material containing highly active, robust, and inactivation-resistant enzyme. In this work, we assess the potential use of potato pulp for phenol removal. Potato pulp is a waste product obtained during starch production. It constitutes the residue that remains after washing out nearly all the starch from potato mash (Lesiecki et al. 2012) and is composed of juice water $(90 \%)$, cellulose, hemicelluloses, pectin, starch, proteins, free amino acids, and salts (Mayer and Hillebrandt 1997; Mayer 1998). The starch manufacturing industry produces huge amounts of potato pulp, running into the hundreds of thousands of tons per year (Mayer 1998). The discharge of potato pulp has become an environmental pollution problem and a cost factor, partly due to the huge quantities of this waste product (Wang et al. 2010). 
Here, we demonstrate that potato pulp, obtained from a potato starch factory, contains active peroxidases. Then, we evaluated this industrial waste for its efficiency in removing phenol and established the optimum conditions to obtain the maximum decontamination efficiency. Then we used a phytotest to evaluate the toxicity of phenol solutions before and after treatment with potato pulp. Finally, we assessed the potential use of potato pulp to reduce phenol content in the effluent from the fine mechanics industry.

\section{Materials and Methods}

\subsection{Plant Material}

Potato pulp was obtained from the starch company PPZ Trzemeszno, Poland. The raw material was portioned, frozen, and stored at $-20{ }^{\circ} \mathrm{C}$. Directly before use, the pulp was thawed in room temperature.

\subsection{Potato Pulp Peroxidase Isolation and Activity}

Peroxidase (POX, EC 1.11.1.7) activity of potato pulp was assessed by measuring the rate of oxidation of pyrogallol to purpurogallin, by following the change in absorbance at $420 \mathrm{~nm}$. The assay medium was composed of $100 \mathrm{mM}$ phosphate buffer ( $\mathrm{pH} 6.0), 39 \mathrm{mM}$ pyrogallol, $23.5 \mathrm{mM} \mathrm{H}_{2} \mathrm{O}_{2}$, and 5-60 mg of potato pulp in a total volume of $1 \mathrm{ml}$. The components of the reaction mixture were mixed in a 2-ml centrifuge tube. The reaction was initiated by adding $\mathrm{H}_{2} \mathrm{O}_{2}$ and conducted for $1 \mathrm{~min}$. After that time, it was stopped by adding $\mathrm{H}_{2} \mathrm{SO}_{4}$ to each tube, to a final concentration of $2 \%$. The $\mathrm{A}_{420}$ was measured immediately after adding $\mathrm{H}_{2} \mathrm{SO}_{4}$ to the medium, in 1-cm quartz cuvettes. Enzyme-free controls were run along with the test samples to correct the assay for non-enzymatic pyrogallol oxidation. POX activity was expressed as the micromoles purpurogallin per minute

To extract the soluble peroxidases and the peroxidases that were ionically bound to the cell wall, the samples consisting of 2.5-10 g of potato pulp were incubated for $3 \mathrm{~h}$ in $25 \mathrm{ml}$ of McIlvaine buffer (127 mM Na $2 \mathrm{HPO}_{4}, 36.9 \mathrm{mM}$ citric acid), $\mathrm{pH} 6.0$, supplemented with $1 \mathrm{M} \mathrm{NaCl}$, under constant agitation. After that, the samples were filtered through nylon mesh and centrifuged for $20 \mathrm{~min}$ at $10,000 \times \mathrm{g}$ at $4{ }^{\circ} \mathrm{C}$ to remove the solid phase. The extract was dialyzed overnight against three changes of $0.25 \times$ McIlvaine buffer. Then, $30 \mu \mathrm{l}$ of dialyzed extract was subjected to native electrophoresis on a polyacrylamide gel. The samples were subjected to discontinuous polyacrylamide gel electrophoresis under non-denaturing, nonreducing conditions, as described by Laemmli (1970) using a stacking gel containing $4 \%(w / v)$ acrylamide and a separating gel containing $15 \%(w / v)$ acrylamide. After the completion of electrophoresis, the gels were stained for POX activity. To visualize POX activity, the gels were placed in Pierce 1-Step TMB-Blotting Substrate Solution (Pierce) until the bands appeared. Peroxidase isoforms stained dark blue. Along with the samples, molecular mass markers (11-245 kDa, 3-Colour Prestained Protein Marker, DNA Gdańsk) were subjected to electrophoretic separation.

\subsection{Phenol Removal Conditions from Synthetic Wastewater}

The reactions for phenol removal were carried out in 15$\mathrm{ml}$ polypropylene tubes containing the reaction mixture composed of aqueous phenol solution, potato pulp, and $\mathrm{H}_{2} \mathrm{O}_{2}$, in a total volume of $2.5 \mathrm{ml}$. The reactions were incubated for 2 or $3 \mathrm{~h}$ at $20 \pm 2{ }^{\circ} \mathrm{C}$ in an orbital shaker at $200 \mathrm{rpm}$. After incubation, the residual phenol was measured spectrophotometrically. Following the measurement, the percentage of phenol removal (removal efficiency) was calculated. If not indicated otherwise, tap water was used as the reaction medium. The stock solutions of phenol and $\mathrm{H}_{2} \mathrm{O}_{2}$ were prepared using distilled water.

To optimize the conditions of phenol removal, the effect of several variables, such as the weight of potato pulp inoculum, $\mathrm{H}_{2} \mathrm{O}_{2}$, phenol concentration, the effect of PEG 3350, $\mathrm{pH}$ of the reaction mixture, the incubation temperature, and shaking rate were investigated. To optimize the mass of the potato pulp inoculum, we determined the efficiency of phenol removal in reactions performed with $200,300,400$, or $500 \mathrm{mg}$ of potato pulp. The samples were added to $2.5 \mathrm{ml}$ of $1 \mathrm{mM}$ phenol solution and the reactions were initiated by supplementing the mixture with $\mathrm{H}_{2} \mathrm{O}_{2}$ to a final concentration of $2.59 \mathrm{mM}$. To determine the optimal $\mathrm{H}_{2} \mathrm{O}_{2}$ concentration, the mixture of $1 \mathrm{mM}$ phenol solution with $400 \mathrm{mg}$ potato pulp was supplemented with $\mathrm{H}_{2} \mathrm{O}_{2}$ to final concentrations of 1.29 to $3.24 \mathrm{mM}$. The efficiency of the removal reaction was tested within the range of initial phenol concentrations from 1 to $6 \mathrm{mM}$. 
The phenol solutions were mixed with $400 \mathrm{mg}$ of potato pulp and then the reaction was initiated by adding $\mathrm{H}_{2} \mathrm{O}_{2}$ to a concentration of $2.59 \mathrm{mM}$. Simultaneously, we tested the effect of polyethylene glycol (PEG) 3350 on the efficiency of the phenol removal reaction, by supplementing the reaction mixtures with $100 \mathrm{mg} / \mathrm{l}$ PEG.

\subsection{Control Variants}

To assess the involvement of the native proteins in phenol removal, we performed control reactions replacing the raw potato pulp with autoclaved potato pulp. The reactions with autoclaved material were carried out in the presence of 1-3 mM phenol and $2.59 \mathrm{mM} \mathrm{H}_{2} \mathrm{O}_{2}$. Furthermore, controls without potato pulp were performed by measuring residual phenol concentration after 2-3 h incubation of 1 to $3 \mathrm{mM}$ phenol solutions in the presence or absence of $\mathrm{H}_{2} \mathrm{O}_{2}$. The reaction mixtures were incubated at room temperature with $200 \mathrm{rpm}$ shaking.

\section{$2.5 \mathrm{pH}$ Range}

To assess the effect of $\mathrm{pH}$ on the efficiency of phenol removal, the reactions were performed using buffered solutions of different $\mathrm{pH}$ values ( $\mathrm{pH} 2$ to 10) as the reaction medium. The reaction buffer consisted of $0.2 \mathrm{M}$ acetic acid, $0.2 \mathrm{M}$ phosphoric acid, and $0.2 \mathrm{M}$ boric acid. Concurrently, tap water (pH 7.3) was tested. The assay was conducted as described above.

\subsection{Effect of Temperature}

To assess the effect of the incubation temperature on the efficiency of phenol removal, the reactions were carried out, in reaction mixtures composed of 1-3 mM phenol, $400 \mathrm{mg}$ potato pulp, and $2.59 \mathrm{mM} \mathrm{H}_{2} \mathrm{O}_{2}$, at temperatures from 10 to $60{ }^{\circ} \mathrm{C}$, for 2 or $3 \mathrm{~h}$. After the reaction was finished, residual phenol was measured spectrophotometrically.

\subsection{Effect of Shaking}

Reactions were performed in optimized conditions, with shaking rate as the variable. We tested shaking rates from 0 to $250 \mathrm{rpm}$. The removal reaction was carried out in the presence of 1-3 $\mathrm{mM}$ phenol, $400 \mathrm{mg}$ potato pulp, $2.59 \mathrm{mM} \mathrm{H}_{2} \mathrm{O}_{2}$, and incubated for 2 or $3 \mathrm{~h}$.
After that, the residual phenol was measured spectrophotometrically.

\subsection{Phenol Removal from Industrial Effluent}

The conditions of phenol removal were essentially the same as for assay with the synthetic wastewater, except the phenol solution was replaced by industrial wastewater from fine mechanics industry of Sohbi Craft Poland. The potato pulp samples of 50 to $200 \mathrm{mg}$ and 0.65 to $3.88 \mathrm{mM} \mathrm{H}_{2} \mathrm{O}_{2}$ were added to the reaction mixtures. Control assays without $\mathrm{H}_{2} \mathrm{O}_{2}$ were performed to estimate the peroxidase-independent phenol removal. The effect of the incubation temperature and $\mathrm{pH}$ on the efficiency of phenol removal was determined as described above. The efficiency of phenol removal was calculated by comparing phenol concentration in postreaction mixture to the phenol concentration in the untreated sample.

\subsection{Phenol Determination}

The phenol concentration in synthetic or industrial wastewater was measured spectrophotometrically using the 4-aminoantipyrine method, as described by Kinsley and Nicell (2000). In brief, $1 \mathrm{ml}$ of post-reaction solution was mixed with $5 \mu \mathrm{l}$ of $\mathrm{NH}_{4} \mathrm{OH}, 5 \mu \mathrm{l}$ of $2 \% 4$ aminoantipyrine, and $10 \mu \mathrm{l}$ of $8 \%$ potassium hexacyaniferrate. After $5 \mathrm{~min}$, the absorbance of the mixture was determined at $510 \mathrm{~nm}$ and compared with the calibration curve in the phenol concentration range of $5-40 \mathrm{mg} / \mathrm{l}$.

\section{$2.10 \mathrm{H}_{2} \mathrm{O}_{2}$ Determination}

The unreacted $\mathrm{H}_{2} \mathrm{O}_{2}$ remaining after the reaction was measured using $1 \mathrm{M}$ potassium iodide. In brief, $500 \mu \mathrm{l}$ of tap water and $1000 \mu \mathrm{l}$ of $1 \mathrm{M} \mathrm{KI}$ were sequentially added to $500 \mu \mathrm{l}$ of post-reaction solution. Then, the absorbance of the mixture was measured at $390 \mathrm{~nm}$ and compared with the calibration curve in the range of $0-1.75 \mathrm{mM} \mathrm{H}_{2} \mathrm{O}_{2}$.

\subsection{Garden Cress (Lepidium sativum) Toxicity Test}

Lepidium sativum seeds were preincubated for $1 \mathrm{~h}$ in tap water and then distributed on Petri dishes lined with wet lignin. Ten seeds were placed into each plate. Thereafter, the seeds were treated with the post-reaction phenol 
solutions and incubated for 24 or $48 \mathrm{~h}$ at room temperature. As negative controls, untreated phenol solutions or phenol solutions incubated with potato pulp without hydrogen peroxide were used. For the positive control, phenol solution was replaced with water. To test the toxicity of hydrogen peroxide alone, the phenol solution was replaced with water and $0.55 \mathrm{mM} \mathrm{H}_{2} \mathrm{O}_{2}$ (the $\mathrm{H}_{2} \mathrm{O}_{2}$ concentration, determined to be present in the mixture after reaction when $1 \mathrm{mM}$ phenol was used) was added to the mixture. After 24 or $48 \mathrm{~h}$, the length of the roots of the seedlings was measured.

\subsection{Statistics}

All of the experiments were conducted as three independent replicates. Mean and standard deviation were calculated. To determine whether the differences between the results were statistically significant, we performed one-way ANOVA with a significance threshold of 0.05 . All the statistical analyses were performed using SigmaPlot 11.0 (Systat Software). The figures show representative results for each experiment.

\section{Results and Discussion}

\subsection{Peroxidase Activity and Isoenzyme Analysis}

The peroxidase activity of potato pulp was assayed by testing its ability to oxidize pyrogallol to purpurogallin in the presence of $\mathrm{H}_{2} \mathrm{O}_{2}$. Increasing the mass of the potato pulp in the reaction mixture resulted in a progressive increase in the production of purpurogallin (Fig. 1a). This finding demonstrates that the peroxidase activity is associated with potato pulp. When the protein preparation, obtained from potato pulp by extraction with $\mathrm{NaCl}$-supplemented buffer, was subjected to native electrophoresis and monitored for peroxidase activity, seven peroxidase isoforms were detected. Among the peroxidase isoforms, the band corresponding to a $72 \mathrm{kDa}$ protein was distinguished by its high staining intensity (Fig. 1b). However, further studies are required to determine whether the band represents a single protein or multiple polypeptides.

\subsection{Phenol Removal from Synthetic Wastewater}

To test the capacity of the potato pulp to remove phenol from a water solution, $400 \mathrm{mg}$ of potato pulp was suspended in $2.5 \mathrm{ml}$ of phenol solution. The range of phenol concentrations tested was from 1 to $6 \mathrm{mM}$. The mixtures were supplemented with $\mathrm{H}_{2} \mathrm{O}_{2}$ to a final concentration of $2.59 \mathrm{mM}$. Simultaneously, a set of samples representing each phenol concentration was supplemented with PEG 3350. Reaction mixtures with and without PEG were accompanied by control samples without $\mathrm{H}_{2} \mathrm{O}_{2}$. The reactions were incubated at room temperature under constant agitation. The residual phenol was measured after 2 or $3 \mathrm{~h}$ of incubation. After both 2 and $3 \mathrm{~h}$ of reaction, we observed very high efficiencies of phenol removal, reaching $99 \%$, in reaction mixtures with initial phenol concentrations from 1 to $3 \mathrm{mM}$. These results are similar to those obtained by González et al. (2012), where phenol at concentrations of 0.1 to $2.65 \mathrm{mM}$ was removed from the solution by hairy roots of Brassica napus with 100-80\% efficiency, respectively. However, our results show higher phenol removal efficiency than that obtained using Raphanus sativus roots (Naghibi et al. 2003).

After $2 \mathrm{~h}$ of reaction, we observed no significant differences in the efficiency of phenol removal between the variants with initial phenol concentrations from 1 to $3 \mathrm{mM}$. After $3 \mathrm{~h}$ of incubation, we observed that the reaction mixtures with $3 \mathrm{mM}$ initial phenol concentration displayed significantly lower phenol removal efficiencies than the 1 or $2 \mathrm{mM}$ variants. Phenol solutions with higher concentration were degraded with significantly lower efficacy. Approximately 80 or $70 \%$ phenol was removed from solutions with initial concentrations of 4 and $6 \mathrm{mM}$, respectively (Fig. 2a, b). However, those results still demonstrate higher removal efficiencies than those obtained by Sosa Alderete et al. (2012), who employed tobacco hairy roots to eliminate phenol from solution. The authors showed that treating 4.25 or $6.37 \mathrm{mM}$ phenol, in the presence of $2.5 \mathrm{mM} \mathrm{H}_{2} \mathrm{O}_{2}$, resulted in the removal of 51.7 or $42.2 \%$ of the pollutant, respectively (Sosa Alderete et al. 2012). The high efficiency of phenol removal by potato pulp was strongly dependent on the presence of $\mathrm{H}_{2} \mathrm{O}_{2}$ in the assay medium. In contrast to the reaction mixtures supplemented with $\mathrm{H}_{2} \mathrm{O}_{2}$, the phenol removal from $\mathrm{H}_{2} \mathrm{O}_{2}$-free samples did not exceed $55 \%$, irrespective of the initial phenol concentration. This finding strongly supports the idea that the highly efficient phenol 
Fig. 1 Peroxidative activity of potato pulp. A series of sample weights was tested for the ability to oxidize pyrogallol to purpurogallin in the presence of $\mathrm{H}_{2} \mathrm{O}_{2}$ (a). The isoenzyme pattern of potato pulp peroxidases. Protein preparations obtained from $2.5,5,7.5$, or $10 \mathrm{~g}$ of potato pulp were separated electrophoretically and stained for peroxidase activity. Since the proteins were subjected to nondenaturing PAGE, the protein molecular mass could not be precisely determined. Therefore, the molecular masses $(\mathrm{kDa})$ of peroxidase isoforms indicated represent an approximation (b)

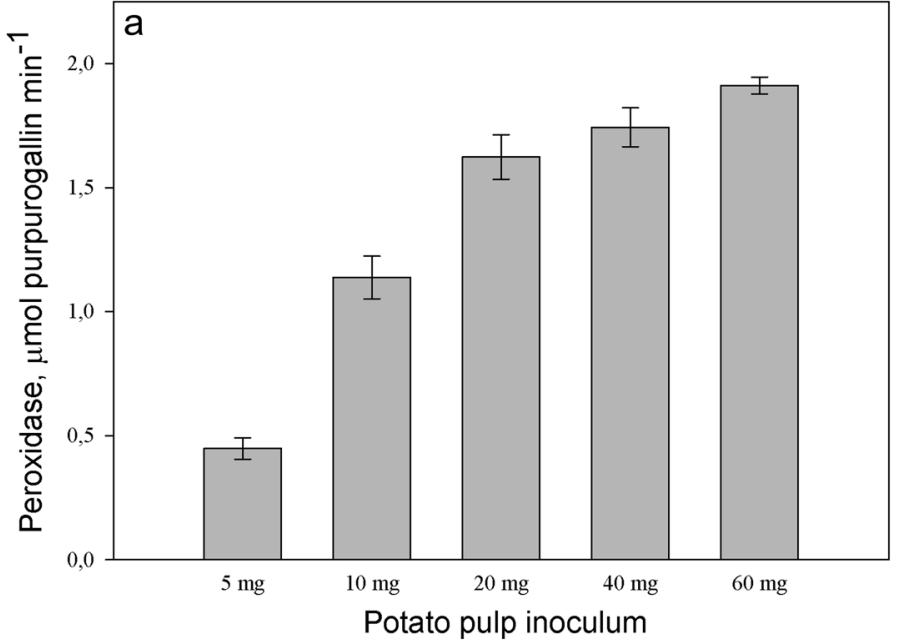

b

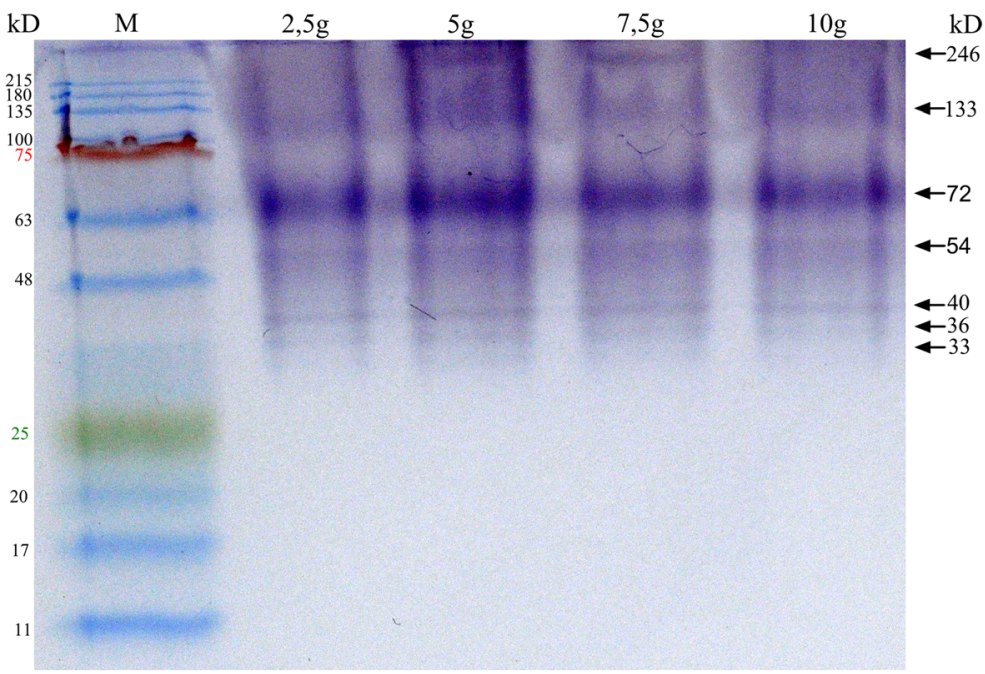

removal is possibly due to peroxidases from the potato pulp (Fig. 2).

To provide further evidence for the enzymatic nature of the phenol degradation process, potato pulp was autoclaved to inactivate enzymes prior to composing the reaction mixture. Phenol concentrations of 1,2 , or $3 \mathrm{mM}$ were selected for this control assay, since they were the most efficiently removed if the native potato pulp was used. The reactions with the autoclaved potato pulp showed much lower removal efficiencies compared to the experiments with native pulp. In contrast to native potato pulp, the average phenol removed by the autoclaved material did not exceed $40 \%$ (Fig. 3a, b). There were no significant differences in phenol removal efficiency between the tested initial phenol concentration variants (Fig. 3a). Partial phenol removal by autoclaved potato pulp might be caused by the adsorption of phenol on the surface of potato pulp. We also observed that the phenol removal efficiencies were negligible if the potato pulp was not added to the reaction, either in the absence or in the presence of $\mathrm{H}_{2} \mathrm{O}_{2}$ (Fig. 3b, c). These findings suggest that the decrease in the phenol concentration observed in our experiments was not due to spontaneous degradation and/or oxidantdependent polymerization of a non-enzymatic nature.

Enzyme inactivation is considered to be the main disadvantage of peroxidase-based phenol removal, significantly elevating the cost of treatment (Feng et al. 2013). Three mechanisms of enzyme inactivation have been proposed as follows: (1) the reaction of an active enzyme intermediate with excess peroxide; (2) destruction of heme by strong reagents, such as free radicals generated during 
Fig. 2 Removal efficiencies at different phenol (phe) concentrations. The efficiency of phenol removal was assessed in assay mixtures composed of phenol solution, potato pulp inoculum, and $\mathrm{H}_{2} \mathrm{O}_{2}$ and in corresponding control mixtures containing phenol and potato pulp but not $\mathrm{H}_{2} \mathrm{O}_{2}$. The efficiency of phenol removal was determined after 2 (a) or 3 (b) hours of incubation in a reaction containing 1-6 mM phenol, $400 \mathrm{mg}$ potato pulp, and $2.59 \mathrm{mM}$ $\mathrm{H}_{2} \mathrm{O}_{2}$ in tap water as a reaction medium. Reaction mixtures were either supplemented (gray bars) or not supplemented (black bars) with 100 mg/l PEG. Different letters denote significant differences at $p \leq 0.05$
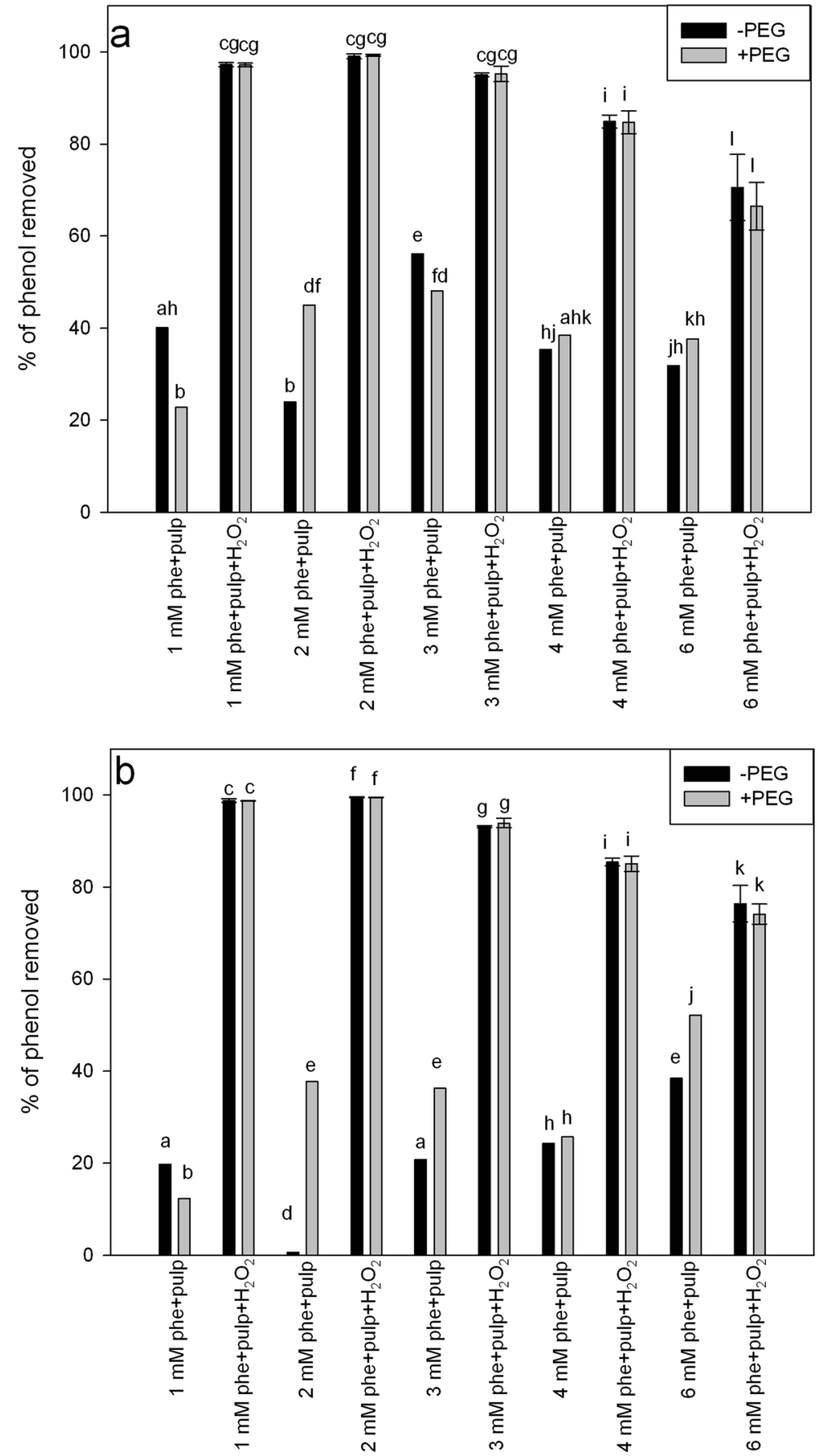

the enzymatic reaction; or (3) adsorption of the enzyme on the precipitated polymerization products, which occludes the enzyme's active site (Mao et al. 2013).

The rate of enzyme inactivation may be decreased by supplementing the reaction medium with a substance that decreases the adsorption of polymers onto the enzyme's active site, using substances such as polyethylene glycol (PEG). Several authors reported a stimulatory effect of PEG on the efficiency of phenol removal by HRP or soybean peroxidase (Kinsley and Nicell 2000). PEG substitutes for the enzyme in adsorption onto the solid polymer products, thus preventing the enzyme from co- 

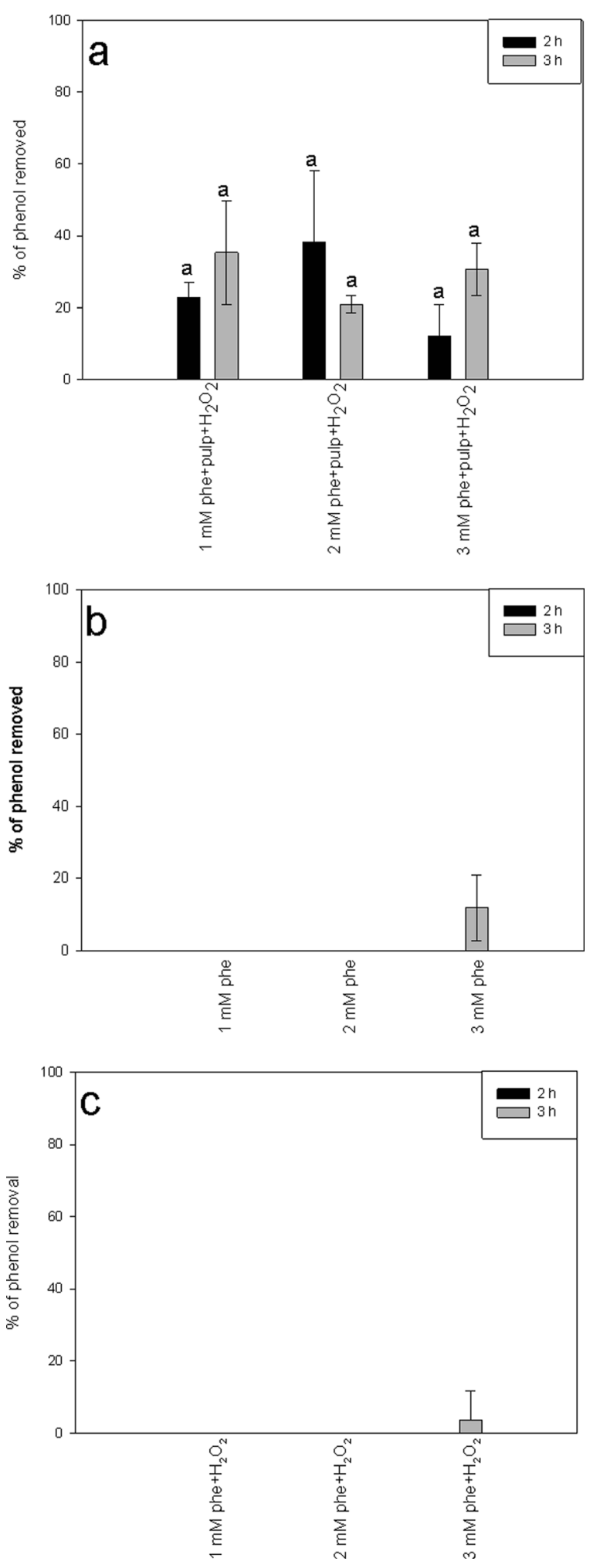

Fig. 3 Control variants. The percentage of phenol (phe) removed after the incubation of $1-3 \mathrm{mM}$ phenol solutions with autoclaved potato pulp and $2.59 \mathrm{mM} \mathrm{H}_{2} \mathrm{O}_{2}$ for 2 (black bars) or 3 (gray bars) hours (a). The percentage of phenol removed after the incubation of water solutions of phenol for 2 or $3 \mathrm{~h}(\mathbf{b})$. The percentage of phenol removed after the incubation of $1-3 \mathrm{mM}$ phenol solutions supplemented with $2.59 \mathrm{mM} \mathrm{H}_{2} \mathrm{O}_{2}$ for 2 or $3 \mathrm{~h}$ (c). Different letters denote significant differences at $p \leq 0.05$

precipitation with the polymeric products (Sakurai et al. 2003). PEG also efficiently suppressed HRP inactivation via heme destruction (Mao et al. 2013). Consequently, the addition of PEG helps to maintain peroxidase activity in the reaction mixture and can reduce the amount of the enzyme required (Qayyum et al. 2009).

When potato pulp was used in the removal process, we observed very high efficiencies of decontamination in the absence of any protective factors and the addition of PEG 3350 did not change phenol depletion at the tested concentrations (Fig. 2). Similarly, phenol removal by tomato hairy roots displayed comparable efficiency in PEG-supplemented and PEG-unsupplemented reaction mixtures. By contrast, adding PEG to the assay medium significantly increased phenol removal by rapeseed hairy roots (Paisio et al. 2010). Similarly, González et al. (2008) reported that PEG supplementation improves the efficiency of the reaction with tomato hairy roots. Wu et al. (1997), using HRP, observed the same improvement in phenol removal after supplementing the reaction medium with PEG. Also, Cooper and Nicell (1996) reported that adding polyethylene glycol resulted in a 22-fold decrease in the amount of enzyme required to effectively perform the removal reaction. The lack of difference between PEG-supplemented and PEGunsupplemented samples observed in our experiments is consistent with the results of Caza et al. (1999), who found that adding PEG did not drastically improve the efficiency of phenol removal by soybean peroxidase.

Another approach to improve the performance of peroxidase in the detoxification of pollutants is the use of enzymes immobilized on natural or synthetic supports. Many materials and different methods, such as glass beads, magnetic beads (Bayramoğlu and Arica 2008), polymers, ion exchange resins, magnetite, aluminum-pillared clay, or sodium alginate encapsulation, have been used for peroxidase immobilization (Alemzadeh and Nejati 2009; Husain and Ulber 2011). Immobilized enzymes usually have a longer operational lifetime, being more stable to physical, chemical, and 
biological denaturing agents (Rao et al. 2010). Immobilization on glutaraldehyde-activated aminopropyl glass beads improved the stability of HRP and the efficiency of phenol removal (Gómez et al. 2006). HRP immobilized by bioaffinity-layering could be successfully used five times, with $100 \%$ conversion of $p$ chlorophenol (Dalal and Gupta 2007). HRP entrapped in alginate capsules could be reused up to four times without any changes in retention activity. Media containing immobilized enzymes are more suitable when large amounts of wastewater need to be processed (Alemzadeh and Nejati 2009). A possible advantage of potato pulp as a tool for the remediation of phenolcontaminated water may be that some of the enzyme is ionically bound to cell wall polymers. Given that enzymes display improved resistance to inactivation when immobilized on a solid support, this fixation of the peroxidase to a solid fraction of the potato pulp may, at least partly, account for the robustness and stability of these enzymes in the assay medium.

\subsection{Residual $\mathrm{H}_{2} \mathrm{O}_{2}$}

Since $\mathrm{H}_{2} \mathrm{O}_{2}$ is toxic for many organisms, it is necessary to determine the residual concentration of $\mathrm{H}_{2} \mathrm{O}_{2}$ before releasing the post-reaction mixtures into the environment (Paisio et al. 2010). We assessed the $\mathrm{H}_{2} \mathrm{O}_{2}$ concentration in post-reaction mixtures initially supplemented with 1, 2, or $3 \mathrm{mM}$ phenol and $2.59 \mathrm{mM} \mathrm{H}_{2} \mathrm{O}_{2}$ and found, that in the post-reaction solution initially supplemented with $1 \mathrm{mM}$ initial phenol, the residual $\mathrm{H}_{2} \mathrm{O}_{2}$ was $0.546 \pm 0.09 \mathrm{mM}$. For the mixtures supplemented with 2 or $3 \mathrm{mM}$ initial phenol, the residual $\mathrm{H}_{2} \mathrm{O}_{2}$ was present at much lower levels, $0.066 \pm 0.002$ or 0.020 $\pm 0.001 \mathrm{mM}$, respectively. Studies on $\mathrm{H}_{2} \mathrm{O}_{2}$ toxicity in an oligodendrocyte cell line indicated that $\mathrm{H}_{2} \mathrm{O}_{2}$ concentrations greater than $0.1 \mathrm{mM}\left(10^{-4} \mathrm{M}\right)$ induce cell toxicity (Bhat and Zhang 1999; Twiner et al. 2001). However, the threshold of $\mathrm{H}_{2} \mathrm{O}_{2}$ toxicity to rainbow trout (Oncorhynchus mykiss) fry and fingerlings is on the order of $10 \mathrm{mM}\left(10^{-2} \mathrm{M}\right)$ or $1 \mathrm{mM}\left(10^{-3} \mathrm{M}\right) \mathrm{H}_{2} \mathrm{O}_{2}$, for 30 or $60 \mathrm{~min}$ of exposure, respectively (Arndt and Wagner 1997). Thus we conclude that the residual $\mathrm{H}_{2} \mathrm{O}_{2}$ in the post-reaction solution should not produce toxic effects when released into the environment if the initial phenol levels were high enough to consume the bulk of the $\mathrm{H}_{2} \mathrm{O}_{2}$ in the reaction. However, the residual $\mathrm{H}_{2} \mathrm{O}_{2}$ may rise to toxic levels for reactions with low initial phenol concentrations. In that case, the $\mathrm{H}_{2} \mathrm{O}_{2}$ concentration in the reaction mixture should be adjusted to assure its efficient scavenging during the incubation.

3.4 Effect of the Weight of the Potato Pulp Inoculum and Hydrogen Peroxide Concentration on Phenol Removal

To optimize the mass of the potato pulp inoculum, we tested weights from 200 to $500 \mathrm{mg}$ per $2.5 \mathrm{ml}$ of reaction mixture. We observed the highest efficiency of phenol removal (from $93.2 \pm 1.1$ to $96.3 \pm 0.2 \%$ ), for both 2 and $3 \mathrm{~h}$ of reaction time, when we used 300 to $500 \mathrm{mg}$ of potato pulp per reaction. There were no statistically significant differences between samples from 300 to $500 \mathrm{mg}$. Supplementing the reaction mixture with more than $500 \mathrm{mg}$ of pulp hampered manipulating the samples because the pulp swelled in the solution. Decreas-

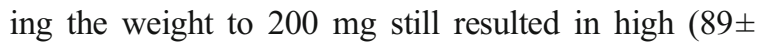
$0.2 \%$ after $3 \mathrm{~h}$ of incubation), but statistically lower phenol removal efficiency compared to the other sample weights (Fig. 4a). The potato pulp tested displayed a higher volume of enzyme source per volume of reaction medium than was described for other systems. Naghibi et al. (2003) tested $0.6 \mathrm{~g}$ of Raphanus sativus root per $20 \mathrm{ml}$ of reaction medium, but obtained only $58 \%$ phenol removal efficiency. However, González et al. (2006, 2012) and Sosa Alderete et al. (2012) demonstrated efficiencies ranging up to $100 \%$ phenol removal, using $0.4 \mathrm{~g}$ of hairy roots per $10 \mathrm{ml}$ of reaction medium. We also tested a series of $\mathrm{H}_{2} \mathrm{O}_{2}$ concentrations to assess the effect of the oxidant concentration on phenol removal efficiency. We found over $90 \%$ phenol removal in the solutions supplemented with all the $\mathrm{H}_{2} \mathrm{O}_{2}$ concentrations tested. However, with $1.29 \mathrm{mM} \mathrm{H}_{2} \mathrm{O}_{2}$, there was no phenol removal after $2 \mathrm{~h}$ of incubation (Fig. 4b). Removal efficiencies with $1.94,2.59$, or $3.24 \mathrm{mM}$ $\mathrm{H}_{2} \mathrm{O}_{2}$ were comparable when measured after 2 and $3 \mathrm{~h}$ of incubation. However, the smallest variation in the removal efficiency, as inferred from the standard deviation values, was observed for $2.59 \mathrm{mM} \mathrm{H}_{2} \mathrm{O}_{2}$; hence, this $\mathrm{H}_{2} \mathrm{O}_{2}$ concentration was chosen for further experiments (Fig. 4b).

\subsection{Effect of the Reaction Mixture $\mathrm{pH}$ on Phenol Removal}

The $\mathrm{pH}$ range tested was from $\mathrm{pH} 2.0$ to 10.0 for initial phenol concentrations from 1 to $4 \mathrm{mM}$ (Fig. 5). The efficiency of phenol removal was measured after 2 or 

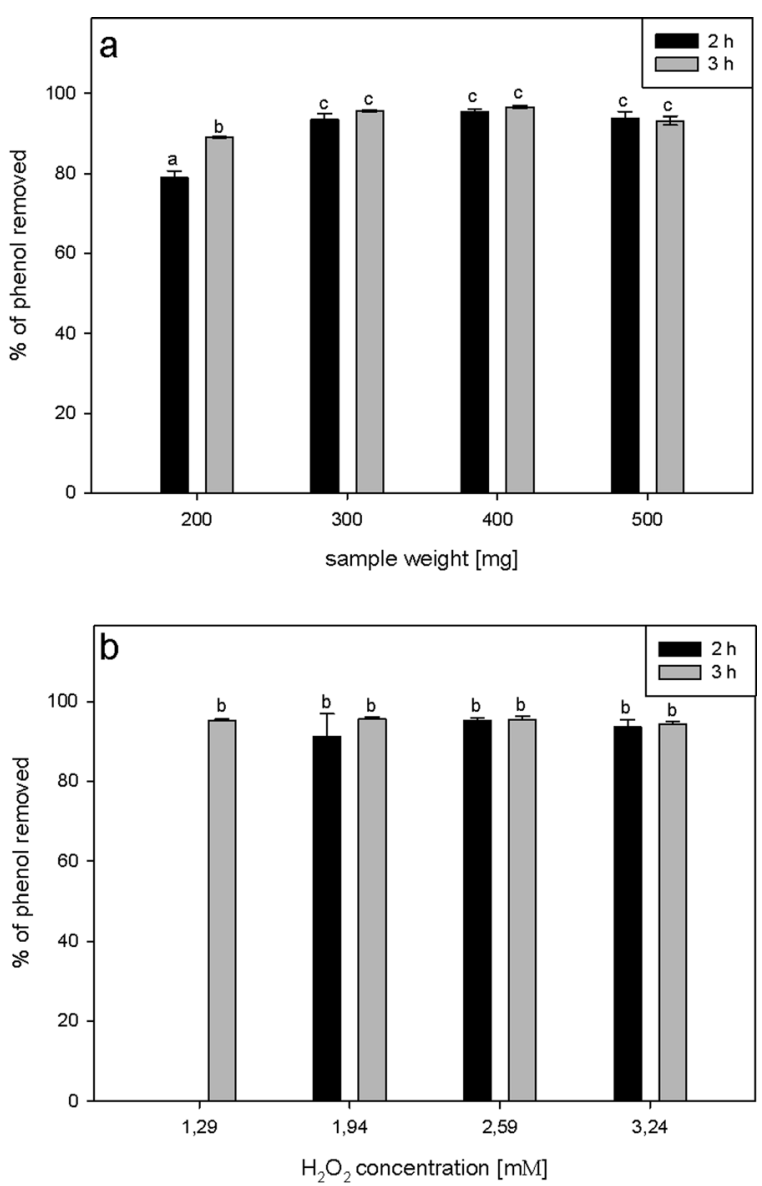

Fig. 4 The effect of sample weight (a) and $\mathrm{H}_{2} \mathrm{O}_{2}$ concentration on phenol (phe) removal. The reactions were performed for 2 (black bars) or 3 (gray bars) hours with $1 \mathrm{mM}$ phenol. Different letters denote significant differences at $p \leq 0.05$

$3 \mathrm{~h}$ of incubation. Each time, $\mathrm{H}_{2} \mathrm{O}_{2}$-free controls were run along with the reactions to monitor peroxidaseindependent changes in phenol concentration. At $\mathrm{pH}$ 2.0, the phenol was either not removed from the solution or the removal efficiency was low (Fig. 5a).

At $\mathrm{pH} 4.0$, we observed better phenol removal efficiencies, with the highest reaching over $80 \%$ for the $2 \mathrm{mM}$ initial phenol concentration, whereas at the same pH, González et al. (2006) obtained phenol removal efficiency of about $45 \%$. Our results are similar to those of Caza et al. (1999), who found that at this $\mathrm{pH}$, about $70 \%$ of the phenol was removed from the reaction medium by soybean peroxidase. For all the phenol concentrations tested, the removal efficiencies at higher $\mathrm{pH}$ were higher than at $\mathrm{pH}$ 2.0. However, we did not observe statistically significant differences among the efficiencies of phenol removal reactions differing in their initial phenol concentrations (Fig. 5b).

At $\mathrm{pH}$ 6.0, a typical optimum $\mathrm{pH}$ for peroxidase activity, reactions resulted in very high phenol removal efficiencies, up to almost $99 \%$ for 1,2 , or $3 \mathrm{mM}$ phenol, but at a phenol concentration of $4 \mathrm{mM}$, we did not observe any phenol removal. There were no statistically significant differences in removal efficiencies between the concentration variants where phenol removal occurred (Fig. 5c). For the same $\mathrm{pH}, 1 \mathrm{mM}$ phenol was removed with an efficiency of about 70 and $90 \%$ by tomato hairy roots (González et al. 2006) and soybean peroxidase (Caza et al. 1999), respectively.

The phenol removal efficiency in the tap water (pH 7.3) as a reaction medium was $99 \%$ for 1,2 , or $3 \mathrm{mM}$ initial phenol concentrations, whereas the removal efficiency at $4 \mathrm{mM}$ initial phenol concentration was $75 \%$ after 3 -h reaction (Fig. $5 \mathrm{~d}$ ). Those findings are in agreement with results obtained by Naghibi et al. (2003), who achieved over $90 \%$ phenol removal efficiency in unbuffered tap water.

At $\mathrm{pH}$ 8.0, we also observed the removal of over $90 \%$ of phenol from the treated solution (Fig. 5e). However, at higher phenol concentrations, the removal efficiencies were lower than in tap water. The highest phenol removal was observed at the $1 \mathrm{mM}$ phenol concentration and reached over $96 \%$, whereas at this $\mathrm{pH}$, hairy roots and soybean peroxidase removed about 70 and $85 \%$ of the phenol, respectively (González et al. 2006; Caza et al. 1999). The removal efficiency gradually decreased with increasing phenol concentration to $66 \%$ at $4 \mathrm{mM}$ phenol (Fig. 5e). At $\mathrm{pH} \mathrm{10,} \mathrm{which} \mathrm{was} \mathrm{the}$ highest $\mathrm{pH}$ tested, we observed a significant decrease in phenol removal, irrespective of the initial phenol concentration in the reaction mixture (Fig. 5f).

The results of the assays on the effect of $\mathrm{pH}$ show that phenol can be efficiently removed from the medium at $\mathrm{pH} 6$ to 8 , and the buffer may be replaced with tap water without compromising the removal efficiency. Irrespective of the $\mathrm{pH}$, the efficiency of phenol removal was either significantly reduced, or did not occur, unless $\mathrm{H}_{2} \mathrm{O}_{2}$ was added to the reaction mixture (Fig. 5a-f). Our results are consistent with those of González et al. (2006) who reported that, using tomato hairy roots, high phenol removal efficiencies were observed in the $\mathrm{pH}$ range 

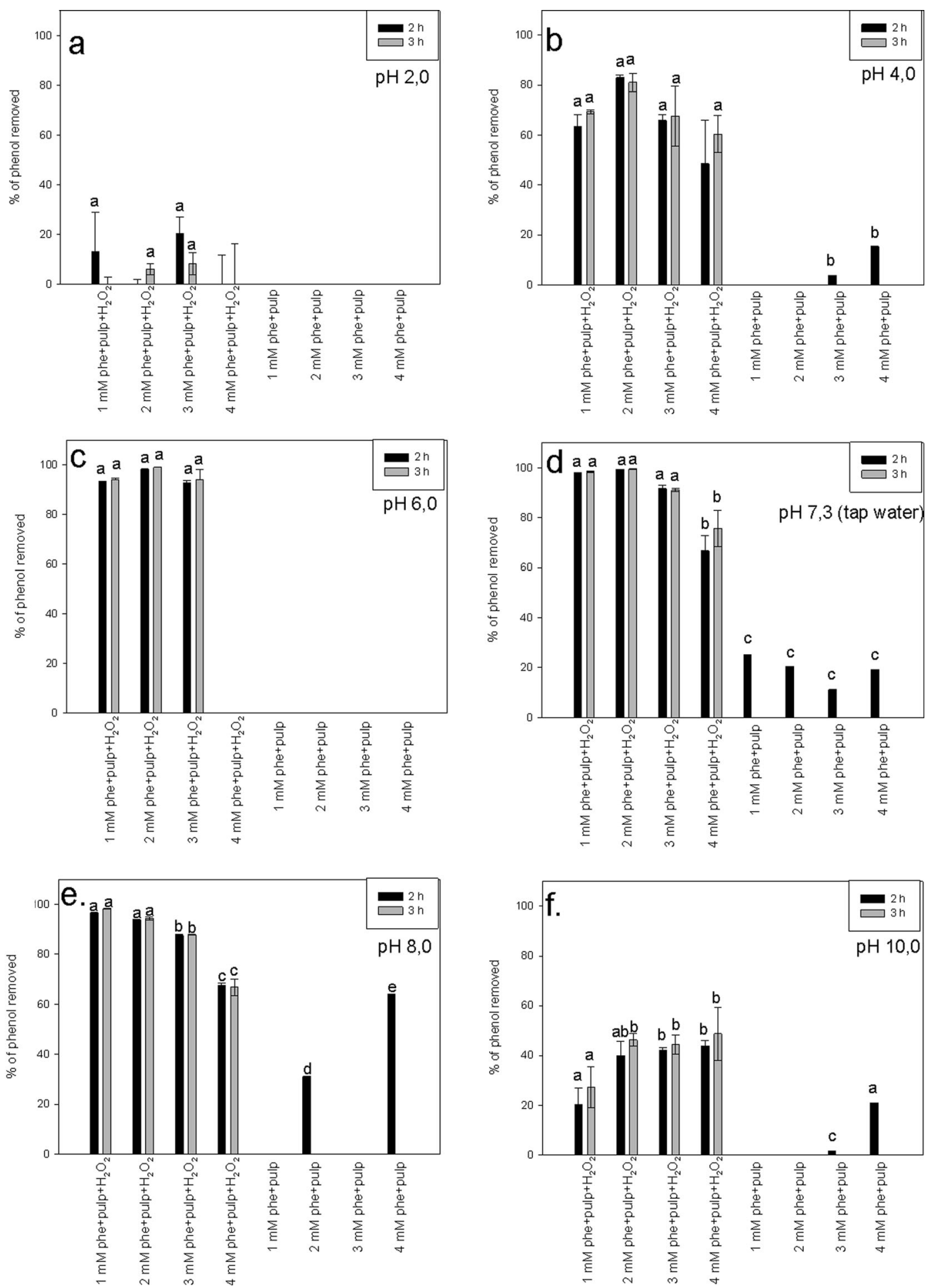

Fig. 5 The effect of $\mathrm{pH}$ on the efficiency of phenol (phe) removal. Efficiency of phenol removal was assessed in assay mixtures composed of phenol solution, potato pulp inoculum, and $\mathrm{H}_{2} \mathrm{O}_{2}$ and in corresponding control mixtures containing phenol and potato pulp but not $\mathrm{H}_{2} \mathrm{O}_{2}$. The assays were carried on at $\mathrm{pH} 2.0$

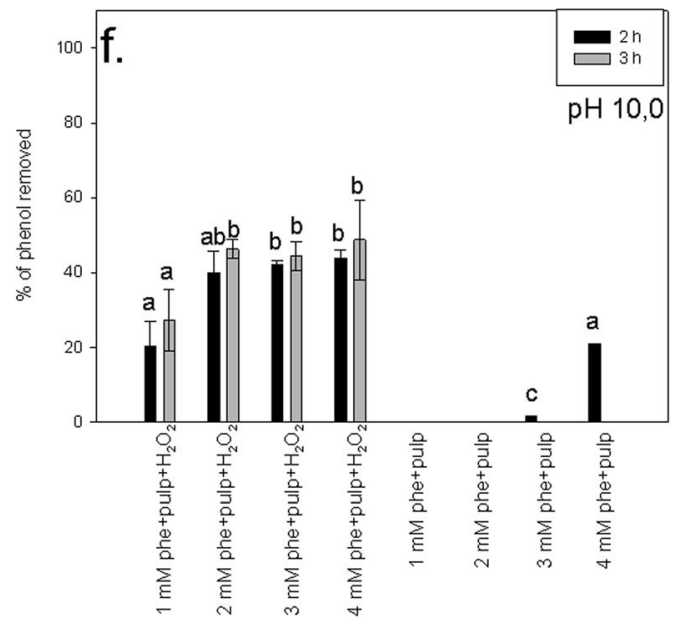

(a), $\mathrm{pH} 4.0$ (b), $\mathrm{pH} 6.0$ (c), $\mathrm{pH} 7.3$ (tap water) (d), $\mathrm{pH} 8.0$ (e), or $\mathrm{pH}$ 10.0 (f). The reactions were incubated for 2 (black bars) or 3 (gray bars) hours. Different letters denote significant differences at $p \leq$ 0.05 
from 4 to 9, with an optimal $\mathrm{pH}$ of 7.5. Similarly, Caza et al. (1999) and Wu et al. (1997) observed peroxidase activity and resulting phenol removal at a wide range of $\mathrm{pH}$ values, from 4 to 9 , and from 4 to 10 , respectively, with the neutral $\mathrm{pH}$ as optimal. By contrast, Kalaiarasan and Palvannan (2014) observed that stabilized horseradish peroxidase displayed the highest phenol removal efficiency at pH 4.2.

\subsection{Effect of Temperature on Phenol Removal}

Peroxidases usually have a wide temperature range within which their activity is maintained (González et al. 2006). Here, we studied the efficiency of phenol removal at temperatures from 10 to $60{ }^{\circ} \mathrm{C}$. We observed that phenol removal displayed high efficiency within the tested temperature range. In the presence of $1 \mathrm{mM}$ phenol, the removal efficiency did not drop below $95 \%$, even at the highest temperature tested (Fig. 6a, b). Similarly, the removal efficiency for $2 \mathrm{mM}$ phenol was $97 \%$ at $10{ }^{\circ} \mathrm{C}$ after $2 \mathrm{~h}$ of incubation and did not significantly change over the entire temperature range (Fig. 6c, d). The most distinct differences in phenol removal efficiencies at different temperatures were observed if the reaction was carried out in the presence of $3 \mathrm{mM}$ phenol. In that case, at both 10 and $60{ }^{\circ} \mathrm{C}$, we observed a slight inhibitory effect on the reaction; however, the removal efficiencies were still over $88 \%$ and we detected no significant differences within the tested temperature range (Fig. 5e, f). For comparison, Kalaiarasan and Palvannan (2014) reported that native HRP lost its activity at $40{ }^{\circ} \mathrm{C}$. However, the enzyme's capacity for phenol removal was maintained at higher temperatures $\left(65^{\circ} \mathrm{C}\right)$ if dextran and sodium alginate were added to the reaction mixture. By contrast, González et al. (2006) observed the highest phenol removal efficiency at 40 and $60{ }^{\circ} \mathrm{C}$, using tomato hairy roots.

\subsection{Effect of Shaking Rate on Phenol Removal}

Most studies testing the ability of peroxidases to detoxify phenol solutions used shaking rates from 50 to $200 \mathrm{rpm}$ to achieve optimal results (González et al. 2008, 2013; Paisio et al. 2010; Gholizadeh et al. 2013; Asadgol et al. 2014; Kalaiarasan and Palvannan 2014; Malani et al. 2013; Abdallah 2013;
Angelini et al. 2014). However, to the best of our knowledge, assessing the effect of various shaking rates on the efficiency of phenol removal by peroxidase has not yet been tested as a distinct experiment. To assess the effect of shaking rate on phenol removal by potato pulp, the reaction mixtures subjected to shaking rates from 50 to $200 \mathrm{rpm}$ were compared to the control, which was mixed after the reaction mixture was composed, and then left unshaken. The differences in the removal efficiency between the shaken samples compared to the control were the most obvious for the $1 \mathrm{mM}$ phenol solutions. The variants that were not shaken displayed phenol removal efficiencies of $70 \%$, whereas shaking the samples enabled almost $100 \%$ phenol removal within the entire range of shaking intensities (Fig. 7a, b). In the case of $2 \mathrm{mM}$ phenol, the unshaken controls displayed removal efficiencies of $85 \%$, significantly lower than in the agitated variants. Agitating samples at $50 \mathrm{rpm}$ increased phenol removal up to $98 \%$. The other variants also displayed removal efficiencies close to $100 \%$ (Fig. 7c, d). After 2 and $3 \mathrm{~h}$ of reaction, there were no statistically significant differences in phenol removal efficiencies at shaking rates from 50 to $200 \mathrm{rpm}$. Slightly lower removal efficiencies were detected for reaction mixtures with $3 \mathrm{mM}$ phenol. The unshaken controls displayed removal efficiencies of $87 \%$, and the efficiencies did not significantly change over the agitation rates applied, except the samples subjected to $150 \mathrm{rpm}$, after 2-h incubation, rising to over $90 \%$ phenol removal (Fig. 7e, f).

We show that the efficiency of the removal reaction is dependent on agitating the samples, for reaction mixtures with 1 or $2 \mathrm{mM}$ phenol, whereas shaking does not affect phenol removal at higher concentrations of the pollutant. Moreover, the reaction's efficiency remained unchanged throughout the range of shaking intensities tested (Fig. 7). These finding may provide clues for the optimization of energy usage by future technology employing potato pulp for phenol removal from wastewater.

\subsection{Lepidium sativum Toxicity Test}

To find out whether the removal of phenol catalyzed by the potato pulp peroxidase reduced the toxicity of the phenol solution, we compared the root growth 

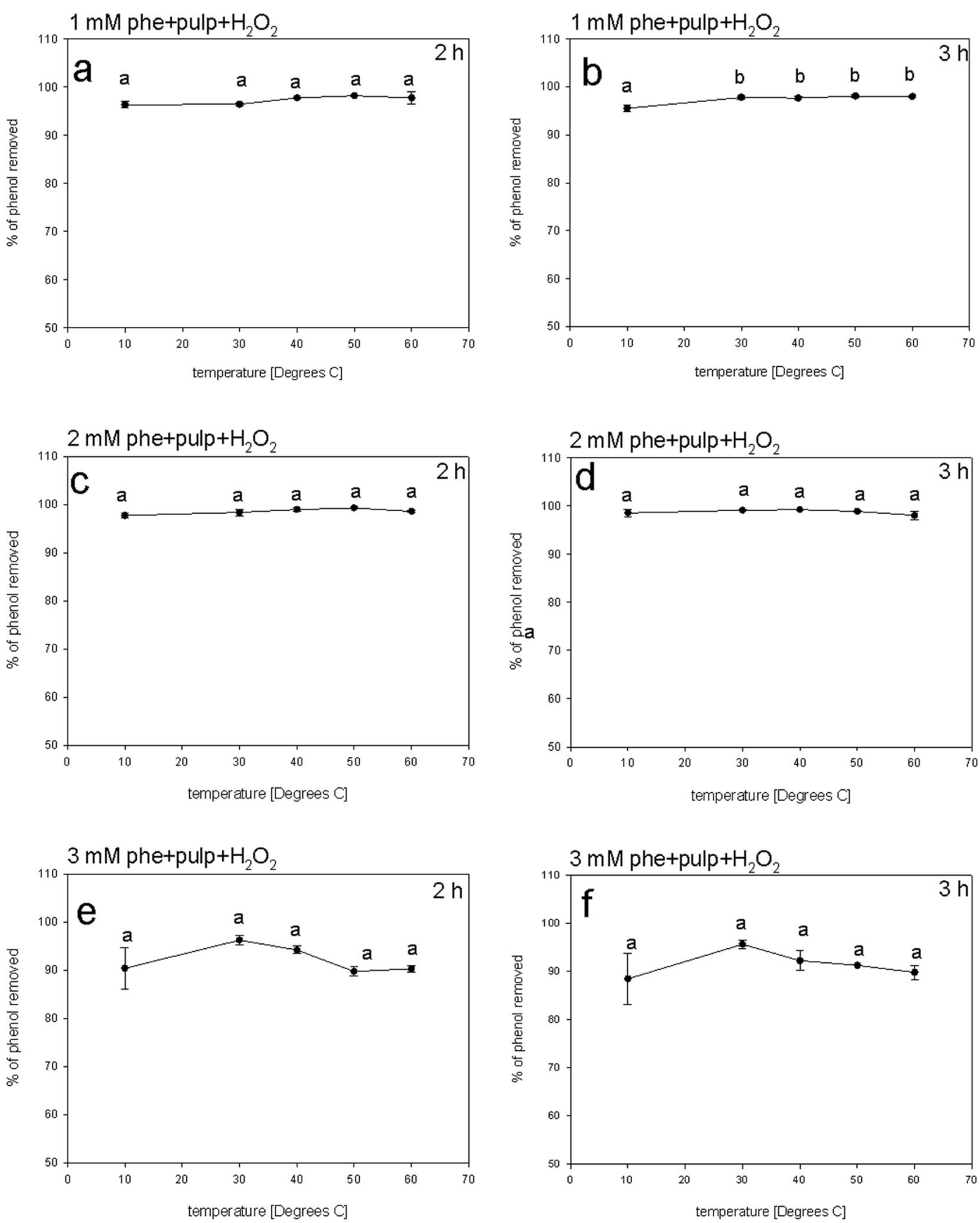

Fig. 6 The effect of temperature on the efficiency of phenol (phe) removal. Efficiency of phenol removal was assessed in assay mixtures composed of phenol solution, potato pulp inoculum, and $\mathrm{H}_{2} \mathrm{O}_{2}$. The assays were incubated at different temperatures.

response of Lepidium sativum seedlings treated with the post-reaction mixtures to seedlings treated with unreacted phenol solution, for initial phenol concentrations of 1-4 mM. Concurrently, separate sets of

The percentage of phenol removal was determined after $2(\mathbf{a}, \mathbf{c}, \mathbf{e})$ or $3(\mathbf{b}, \mathbf{d}, \mathbf{f})$ hours of incubation. The assay solutions were initially supplemented with 1 (a, b), 2 (c, d), or 3 (e, f) $\mathrm{mM}$ phenol. Different letters denote significant differences at $p \leq 0.05$

seedlings were treated with $\mathrm{H}_{2} \mathrm{O}_{2}$-unsupplemented mixtures of phenol and potato pulp, to discriminate between the effects of peroxidase-dependent and peroxidase-independent detoxification. Additionally, 

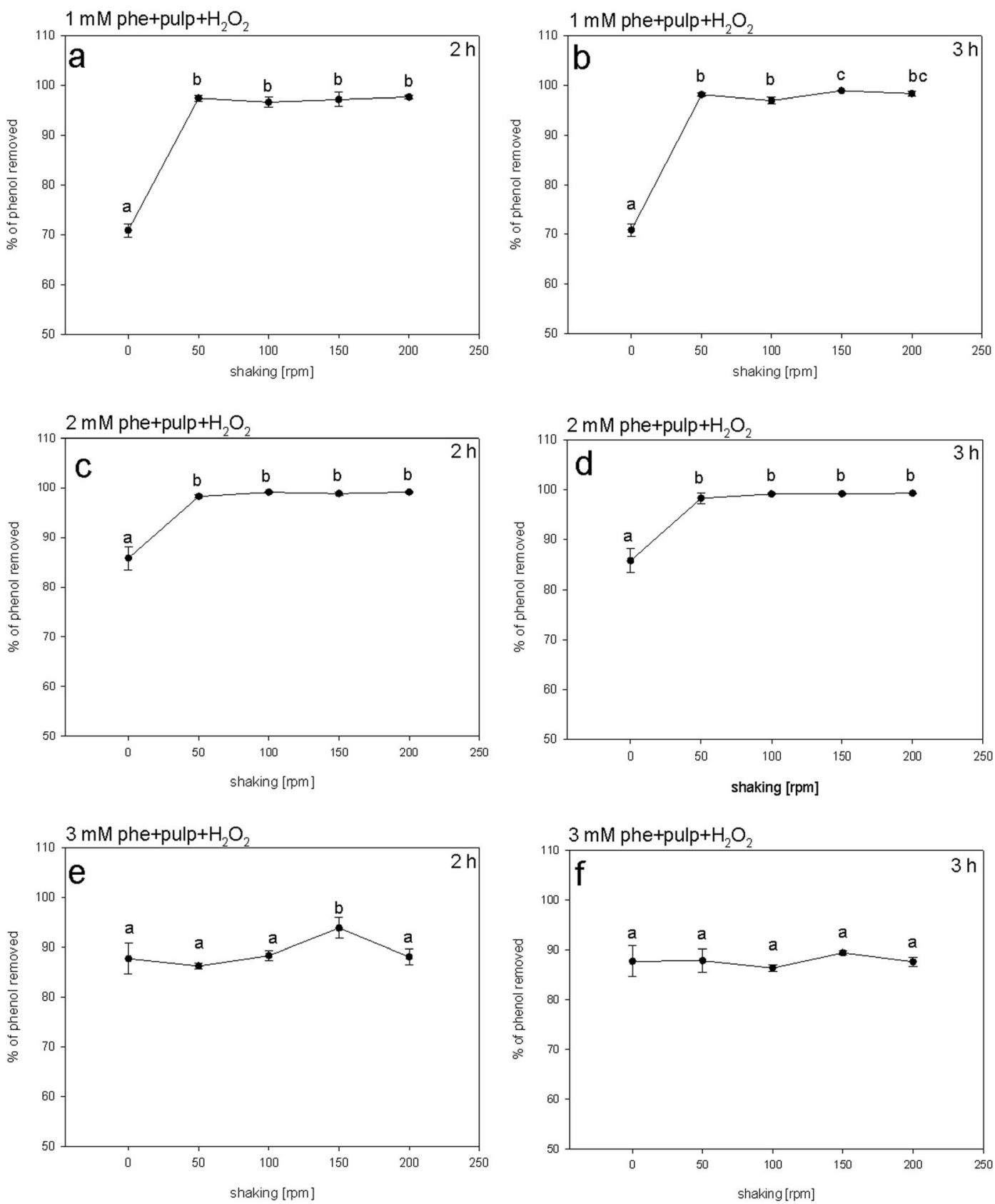

Fig. 7 The effect of shaking rate on the efficiency of phenol (phe) removal. Efficiency of phenol removal was assessed in assay mixtures composed of phenol solution, potato pulp inoculum, and $\mathrm{H}_{2} \mathrm{O}_{2}$. The assays were conducted at different shaking rates.

to assess the toxicity of the residual $\mathrm{H}_{2} \mathrm{O}_{2}$, a set of seedlings was incubated with $\mathrm{H}_{2} \mathrm{O}_{2}$ solution at a concentration equivalent to that of the post-reaction mixture. The length of seedling roots was determined after 24 or $48 \mathrm{~h}$ of incubation (Fig. 8).

The percentage of phenol removed was determined after $2(\mathbf{a}, \mathbf{c}, \mathbf{e})$ or $3(\mathbf{b}, \mathbf{d}, \mathbf{f})$ hours of incubation. The assay solutions were initially supplemented with $1(\mathbf{a}, \mathbf{b}), 2$ (c, d), or $3(\mathbf{e}, \mathbf{f}) \mathrm{mM}$ phenol. Different letters denote significant differences at $p \leq 0.05$

When the Lepidium sativum seedlings were incubated for $24 \mathrm{~h}$ in the presence of phenol, we observed progressive inhibition of seedling root growth. Treatment with $1 \mathrm{mM}$ phenol did not significantly reduce seedling root length, whereas, higher phenol 
Fig. 8 Lepidium sativum toxicity test. The length of the seedling root is shown. L. sativum seeds were treated for 24 (a) or 48 (b) hours with distilled water (control), $0.55 \mathrm{mM} \mathrm{H}_{2} \mathrm{O}_{2}$ (control $+\mathrm{H}_{2} \mathrm{O}_{2}$ ), 1-4 mM phenol (phe) solutions, phenol solution incubated with potato pulp but not provided with $\mathrm{H}_{2} \mathrm{O}_{2}$ (phe + pulp) or the corresponding postreaction solution (PRx). Different letters denote significant differences at $p \leq 0.05$
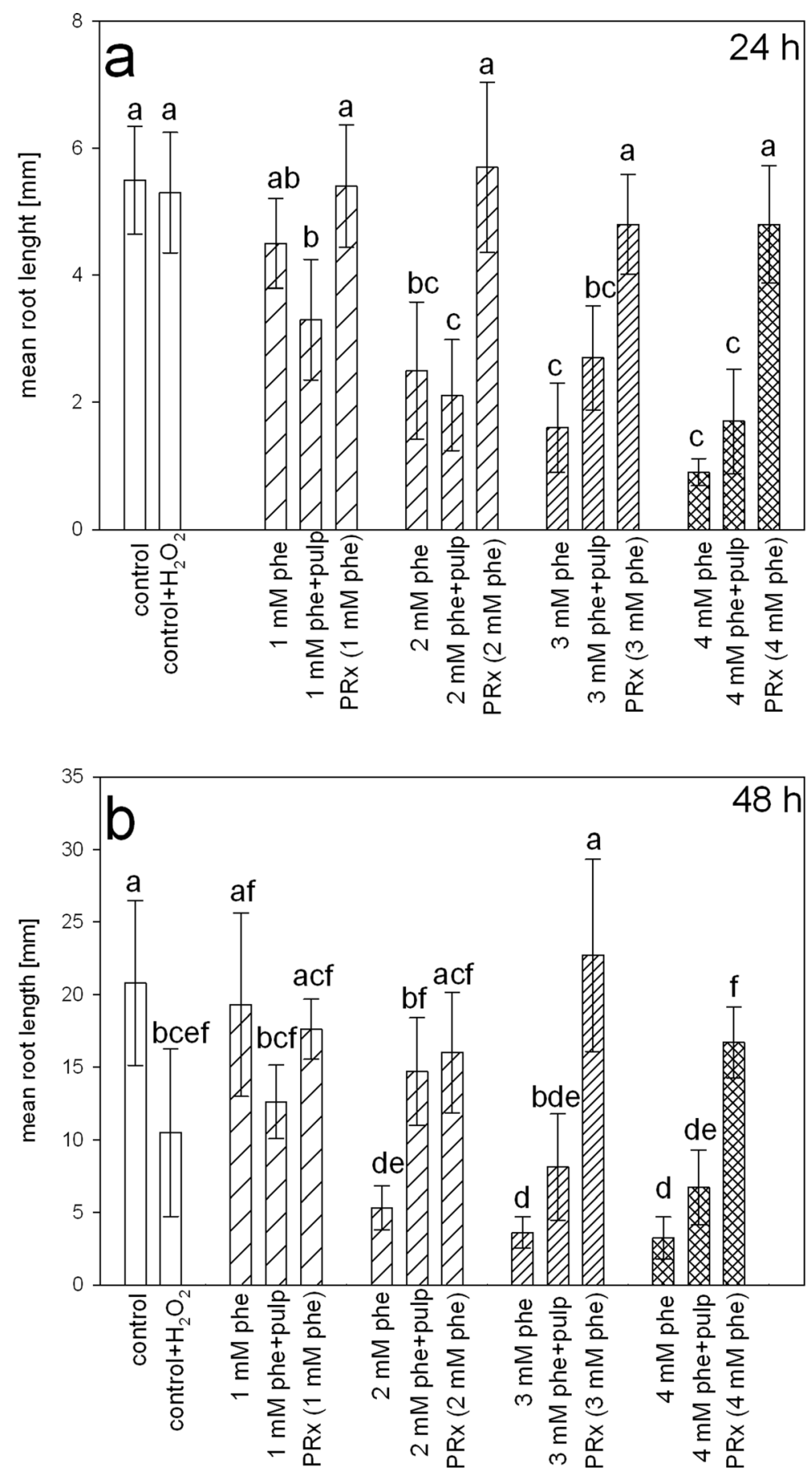

concentrations displayed a gradually increasing inhibitory effect on root growth. Roots of seedlings treated with $\mathrm{H}_{2} \mathrm{O}_{2}$-free, phenol-pulp mixture remained approximately at the same length as those incubated in the presence of unreacted phenol. By contrast, roots of seedlings treated with post-reaction solution were significantly longer than roots of seedlings treated with unreacted phenol or phenol incubated with potato pulp, being comparable to the roots of control plants, irrespective of the initial phenol concentration (Fig. 8).

Similar to the seedlings subjected to the 24-h incubation, those treated for $48 \mathrm{~h}$ with the phenol 
solutions displayed strong reductions in the root length if 2, 3, or $4 \mathrm{mM}$ phenol was used. Seedlings treated with $1 \mathrm{mM}$ phenol did not display statistically significant differences in root growth rate, compared to those subjected to treatment with the relevant post-reaction solution. However, there were significant reductions in root length between seedlings incubated with $1 \mathrm{mM}$ phenol or the postreaction solution, when compared to those treated with $1 \mathrm{mM}$ phenol mixed with potato pulp. The reduction in the root growth, due to presence of 2$4 \mathrm{mM}$ phenol, was fully abolished if phenol solution was replaced by the relevant post-reaction mixture (Fig. 8).

Seedlings grown for $48 \mathrm{~h}$ in the presence of a mixture of pulp and 3 or $4 \mathrm{mM}$ phenol (but devoid of $\mathrm{H}_{2} \mathrm{O}_{2}$ ) produced slightly longer roots than those treated with unreacted phenol. However, the differences did not pass the significance test. In the case of seedlings incubated with $2 \mathrm{mM}$ phenol-potato pulp mixture, root lengths were similar to those incubated with $2 \mathrm{mM}$ post-reaction solution. Having analyzed the results of the $24 \mathrm{~h}$ incubation, we observed that seedling growth was not arrested due to the presence of residual $\mathrm{H}_{2} \mathrm{O}_{2}$. Based on that observation, we concluded that the concentration of hydrogen peroxide used had no toxic effect on Lepidium sativum seedlings at the initial phase of root growth (Fig. 8a). However, the 48-h exposure to this reagent resulted in a significant decrease in root length. This suggests that prolonged presence of oxidant concentrations similar to those remaining in the post-reaction mixtures may have a toxic effect. However, any growth inhibition was not observed if the post-reaction mixture was used instead of the $\mathrm{H}_{2} \mathrm{O}_{2}$ solution (Fig. 8). This finding could be explained by the scavenging of the residual $\mathrm{H}_{2} \mathrm{O}_{2}$ at the expense of the residual phenol by secretory peroxidase of Lepidium sativum during seedling incubation.

Our results are consistent with those obtained by Angelini et al. (2014), who demonstrated, using Lactuca sativa seedlings, that the toxicity caused by 2,4 -dichlorophenol was completely abolished after removal of the pollutant with Brassica napus hairy roots. Paisio et al. (2010) reported that Rhinella arenarum embryos treated with postreaction solution from rapeseed hairy roots displayed significantly reduced mortality for initial phenol concentrations from 1 to $2.65 \mathrm{mM}$, compared to the corresponding concentrations of unreacted phenol. PEG 3350 in the assay medium significantly enhanced the reduction of phenol toxicity during the phenol removal reaction (Paisio et al. 2010). The results of toxicity tests with onion (Allium cepa) bulbs performed by González et al. (2012) show that phenol removal by tomato hairy root peroxidase significantly reduced the toxicity of the solution originally supplemented with $2.65 \mathrm{mM}$ phenol. Onion bulbs treated with phenol post-reaction solutions displayed an increase of $34 \%$ in root length, compared with the phenol solution of the same concentration (González et al. 2012).

\subsection{Phenol Removal from Industrial Effluent}

The phenol concentration in the samples of the industrial effluent used in this study varied between 0.02 and $0.1 \mathrm{mM}$. Since the phenol concentrations in the industrial effluent were much lower compared to the synthetic wastewater prepared in the laboratory, we anticipated that smaller inocula of potato pulp will be required for phenol removal. Therefore, 50, 100 , or $200 \mathrm{mg}$ of potato pulp samples were assessed for their ability to decrease phenol content in the industrial wastewater. It was determined that using $100 \mathrm{mg}$ of potato pulp resulted in the highest phenol removal from the industrial effluent. In contrast to the synthetic wastewater, up to $80 \%$ of phenol was removed by potato pulp from industrial wastewater in the absence of $\mathrm{H}_{2} \mathrm{O}_{2}$ (Fig. 9a). This finding may suggest effective phenol sorption to pulp solids. Increasing $\mathrm{H}_{2} \mathrm{O}_{2}$ concentration until $1.94 \mathrm{mM}$ did not affect removal efficiency. However, $2.59 \mathrm{mM} \mathrm{H}_{2} \mathrm{O}_{2}$ or higher concentrations enhanced the removal efficiency (Fig. 9b).

The efficiency of phenol removal in $\mathrm{H}_{2} \mathrm{O}_{2}$ unsupplemented medium progressively decreased under incubation temperature of $40{ }^{\circ} \mathrm{C}$ or higher. However, the removal process was still effective in $\mathrm{H}_{2} \mathrm{O}_{2}$-supplemented samples (Fig. 9c) suggesting that peroxidase-based phenol removal was less susceptible to high temperature than in $\mathrm{H}_{2} \mathrm{O}_{2}$-free controls. We also observed, that the reaction could be conducted over a wide range of the $\mathrm{pH}$ range. The significant decrease in phenol removal efficiency was observed only when the reaction was conducted at pH 10 (Fig. 9d). 

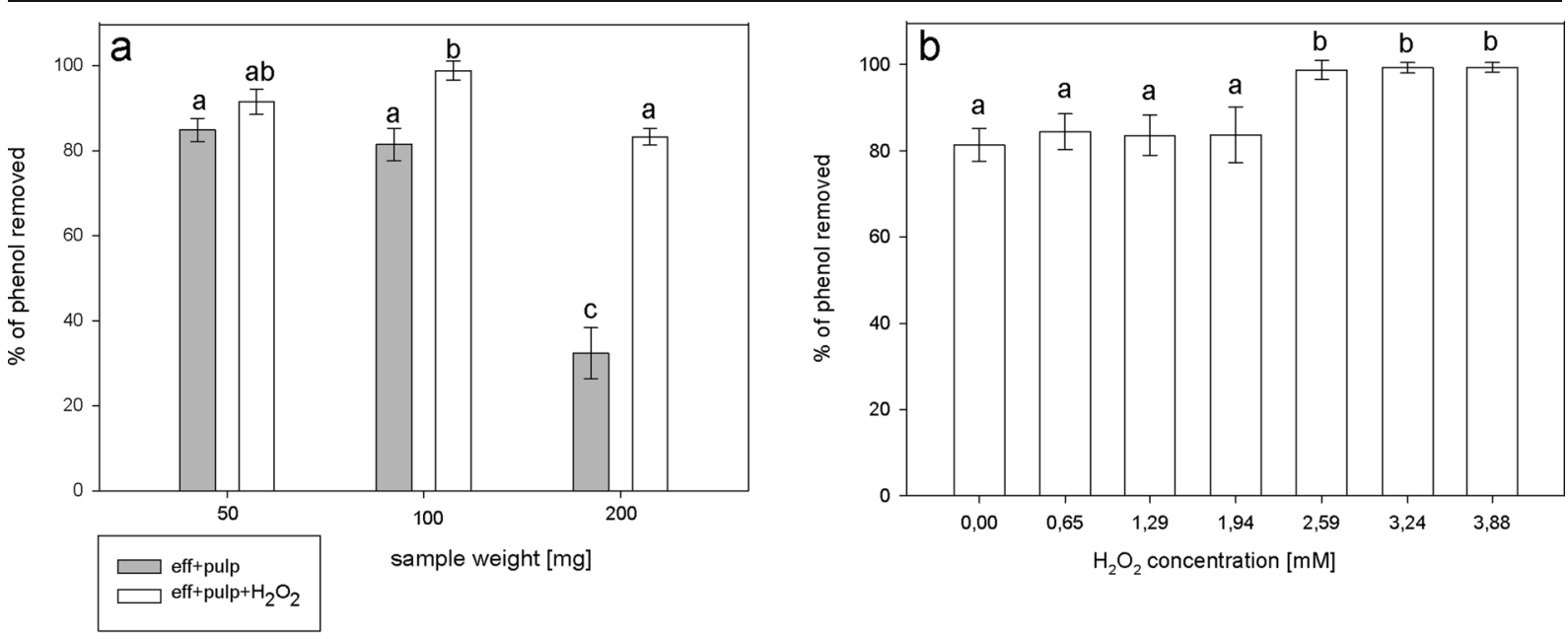

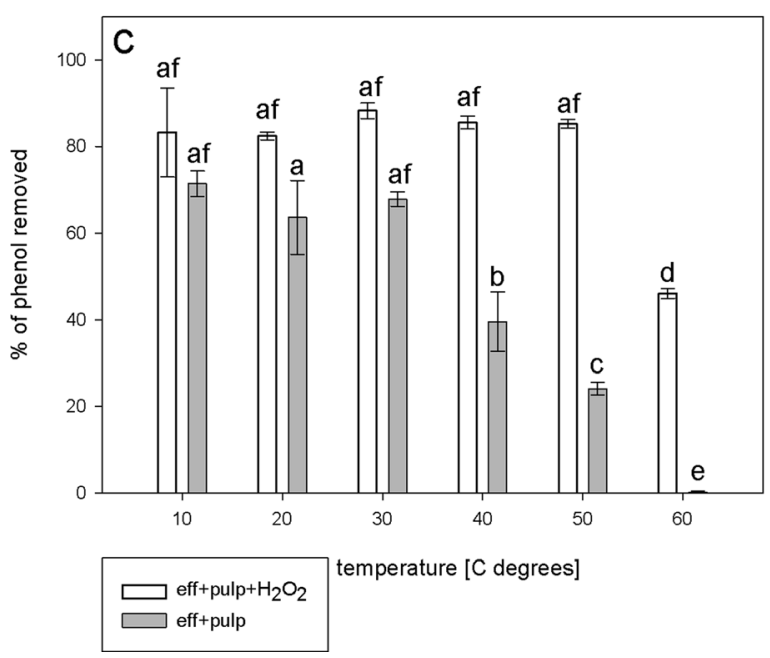

Fig. 9 Phenol removal from industrial effluent. Different conditions for phenol removal were tested. The reactions were performed for $2 \mathrm{~h}$ with 50-200 mg of potato pulp and supplemented with $2.59 \mathrm{mM} \mathrm{H} \mathrm{O}_{2}$ (a). The effect of $\mathrm{H}_{2} \mathrm{O}_{2}$ concentration on phenol removal (b). The effect of temperature on phenol removal

\section{Conclusion}

The bottleneck for systems using peroxidases for the decontamination of phenol-polluted wastewater is the inaccessibility of a low-cost enzyme source, which would satisfy the demands of large-scale remediation. The use of potato pulp for remediation may help to overcome this difficulty, since potato starch factories produce hundreds thousands of tons of this material every year as an industrial waste product. Potato pulp provides a good alternative to purified peroxidases, such as HRP, which are expensive and prone to inactivation,

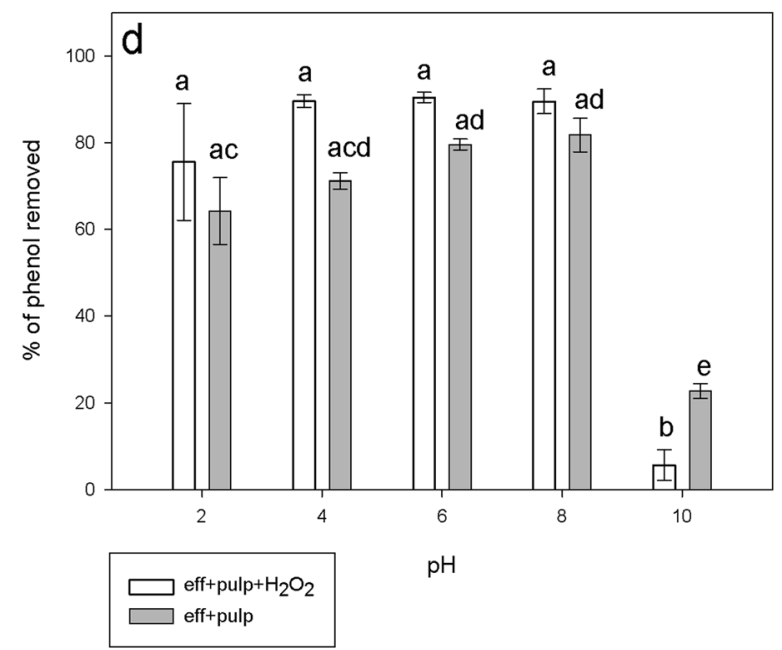

(c). The effect of $\mathrm{pH}$ on phenol removal (d). eff + pulp $+\mathrm{H}_{2} \mathrm{O}_{2}=$ reaction mixture composed of industrial effluent, potato pulp and supplemented with $\mathrm{H}_{2} \mathrm{O}_{2}$, eff + pulp = industrial effluent incubated with potato pulp, but devoid of $\mathrm{H}_{2} \mathrm{O}_{2}$. Different letters denote significant differences at $p \leq 0.05$

and to hairy root cultures, which — while ensuring good removal efficiencies - are also costly, due to the high cost of culture media. The present work opens the possibility of further research aimed at scaling-up the process and construction of bioreactors adapted to largescale decontamination of phenol-polluted wastewater with potato pulp.

Acknowledgments This work was financially supported by a grant from the National Science Centre, Poland (Grant No. 005/B/ P01/2010/39) and by the Kuyavian-Pomeranian Marshal's Office PhD student scholarship program "Step into the future-scholarships for PhD students, $5^{\text {th }}$ edition". 
Open Access This article is distributed under the terms of the Creative Commons Attribution 4.0 International License (http:// creativecommons.org/licenses/by/4.0/), which permits unrestricted use, distribution, and reproduction in any medium, provided you give appropriate credit to the original author(s) and the source, provide a link to the Creative Commons license, and indicate if changes were made.

\section{References}

Abdallah, M. A. M. (2013). The potential of different bio adsorbents for removing phenol from its aqueous solution. Environmental Monitoring and Assessment, 185(8), 64956503.

Aitken, M. D., Venkatadri, R., \& Irvine, R. L. (1989). Oxidation of phenolic pollutants by a lignin degrading enzyme from the white-rot fungus Phanerochaete chrysosporium. Water Research, 23(4), 443-450.

Alemzadeh, I., \& Nejati, S. (2009). Phenols removal by immobilized horseradish peroxidase. Journal of Hazardous Materials, 166(2-3), 1082-1086.

Angelini, V. A., Orejas, J., Medina, M. I., \& Agostini, E. (2011). Scale up of 2,4-dichlorophenol removal from aqueous solutions using Brassica napus hairy roots. Journal of Hazardous Materials, 185(1), 269-274.

Angelini, V. A., Agostini, E., Medina, M. I., \& González, P. S. (2014). Use of hairy roots extracts for 2,4-DCP removal and toxicity evaluation by Lactuca sativa test. Environmental Science and Pollution Research, 21(4), 2531-2539.

Arndt, R. E., \& Wagner, E. J. (1997). The toxicity of hydrogen peroxide to rainbow trout Oncorhynchus mykiss and cutthroat trout Oncorhynchus clarki fry and fingerlings. Journal of the World Aquaculture Society, 28(2), 150157.

Asadgol, Z., Forootanfar, H., Rezaei, S., Mahvi, A. H., \& Faramarzi, M. A. (2014). Removal of phenol and bisphenol-A catalyzed by laccase in aqueous solution. Journal of Environmental Health Science and Engineering, $12,93$.

Ashraf, H., \& Husain, Q. (2010). Studies on bitter gourd peroxidase catalyzed removal of p-bromophenol from wastewater. Desalination, 262(1), 267-272.

Bayramoğlu, G., \& Arica, M. Y. (2008). Enzymatic removal of phenol and $p$-chlorophenol in enzyme reactor: horseradish peroxidase immobilized on magnetic beads. Journal of Hazardous Materials, 156(1), 148-155.

Bhat, N. R., \& Zhang, P. (1999). Hydrogen peroxide activation of multiple mitogen-activated protein kinases in an oligodendrocyte cell line: role of extracellular signal-regulated kinase in hydrogen peroxide-induced cell death. Journal of Neurochemistry, 72(1), 112-119.

Caza, N., Bewtra, J. K., Biswas, N., \& Taylor, K. E. (1999). Removal of phenolic compounds from synthetic wastewater using soybean peroxidase. Water Research, 33(13), 30123018 .

Cooper, V. A., \& Nicell, J. A. (1996). Removal of phenols from a foundry wastewater using horseradish peroxidase. Water Research, 30(4), 954-964.
Dalal, S., \& Gupta, M. N. (2007). Treatment of phenol wastewater by horseradish peroxidase immobilized by bioaffinity layering. Chemosphere, 67(4), 741-747.

Diao, M., Ouédraogo, N., Baba-Moussa, L., Savadogo, P. W., N'Guessan, A. G., Bassolé, I. H., \& Dicko, M. H. (2011). Biodepollution of wastewater containing phenolic compounds from leather industry by plant peroxidases. Biodegradation, 22(2), 389-396.

El Agha, A., Makris, D. P., \& Kefalas, P. (2008). Peroxidase-active cell free extract from onion solid wastes: biocatalytic properties and putative pathway of ferulic acid oxidation. Journal of Bioscience and Bioengineering, 106(3), 279-285.

Feng, W., Taylor, K. E., Biswas, N., \& Bewtra, J. K. (2013). Soybean peroxidase trapped in product precipitate during phenol polymerization retains activity and may be recycled. Journal of Chemical Technology and Biotechnology, 88(8), 1429-1435.

Gholizadeh, A., Kermani, M., Gholami, M., \& Farzadkia, M. (2013). Kinetic and isotherm studies of adsorption and biosorption processes in the removal of phenolic compounds from aqueous solutions: comparative study. Journal of Environmental Health Science and Engineering, 11, 29.

Gómez, J. L., Bódalo, A., Gómez, E., Bastida, J., Hidalgo, A. M., \& Gómez, M. (2006). Immobilization of peroxidases on glass beads: an improved alternative for phenol removal. Enzyme and Microbial Technology, 39(5), 1016-1022.

González, P. S., Capozucca, C., Tigier, H., Milrad, S., \& Agostini, E. (2006). Phytoremediation of phenol from wastewater, by peroxidases of tomato hairy root cultures. Enzyme and Microbial Technology, 39(4), 647-653.

González, P. S., Agostini, E., \& Milrad, S. R. (2008). Comparison of the removal of 2,4-dichlorophenol and phenol from polluted water, by peroxidases from tomato hairy roots, and protective effect of polyethylene glycol. Chemosphere, 70(6), 982-989.

González, P. S., Maglione, G. A., Giordana, M., Paisio, C. E., Talano, M. A., \& Agostini, E. (2012). Evaluation of phenol detoxification by Brassica napus hairy roots, using Allium cepa test. Environmental Science and Pollution Research International, 19(2), 482-491.

González, P. S., Ontañon, O. M., Armendariz, A. L., Talano, M. A., Paisio, C. E., \& Agostini, E. (2013). Brassica napus hairy roots and rhizobacteria for phenolic compounds removal. Environmental Science and Pollution Research International, 20(3), 1310-1317.

Hamid, M., \& Rehman, K. (2009). Potential applications of peroxidases. Food Chemistry, 115(4), 1177-1186.

Husain, Q., \& Ulber, R. (2011). Immobilized peroxidase as a valuable tool in the remediation of aromatic pollutants and xenobiotic compounds: a review. Critical Reviews in Environmental Science and Technology, 47(8), 770-804.

Jha, P., Jobby, R., Kudale, S., Modi, N., Dhaneshwar, A., \& Desai, N. (2013). Biodegradation of phenol using hairy roots of Helianthus annuus L. International Biodeterioration and Biodegradation, 77, 106-113.

Kalaiarasan, E., \& Palvannan, T. (2014). Removal of phenols from acidic environment by horseradish peroxidase (HRP): aqueous thermostabilization of HRP by polysaccharide additives. Journal of the Taiwan Institute of Chemical Engineers, 45(2), 625-634. 
Kinsley, C., \& Nicell, J. A. (2000). Treatment of aqueous phenol with soybean peroxidase in the presence of polyethylene glycol. Bioresource Technology, 73(2), 139-146.

Laemmli, U. K. (1970). Cleavage of structural proteins during the assembly of the head of bacteriophage T4. Nature, 227(5259), 680-685.

Lesiecki, M., Białas, W., \& Lewandowicz, G. (2012). Enzymatic hydrolysis of potato pulp. Acta Scientiarum Polonorum. Technologia Alimentaria, 11(1), 53-59.

Longoria, A., Tinoco, R., \& Vázquez-Duhalt, R. (2008). Chloroperoxidase-mediated transformation of highly halogenated monoaromatic compounds. Chemosphere, 72(3), 485-490.

Malani, R. S., Khanna, S., \& Moholkar, V. S. (2013). Sonoenzymatic decolourization of an azo dye employing immobilized horse radish peroxidase (HRP): a mechanistic study. Journal of Hazardous Materials, 256-257, 90-97.

Mao, L., Luo, S., Huang, Q., \& Junhe, L. (2013). Horseradish peroxidase inactivation: heme destruction and influence of polyethylene glycol. Scientific Reports, 3, 3126.

Mayer, F. (1998). Potato pulp: properties, physical modification and applications. Polymer Degradation and Stability, 59(1), 231-235.

Mayer, F., \& Hillebrandt, J. O. (1997). Potato pulp: microbiological characterization, physical modification, and application of this agricultural waste product. Applied Microbiology and Biotechnology, 48(4), 435-440.

Michałowicz, J., \& Duda, W. (2007). Phenols - sources and toxicity. Polish Journal of Environmental Studies, 16(3), 347-362.

Naghibi, F., Pourmorad, F., Honary, S., \& Shamsi, M. (2003). Decontamination of water polluted with phenol using Raphanus sativus root. Iranian Journal of Pharmaceutical Research, 2(1), 29-32.

Paisio, C. E., González, P. S., Gerbaudo, A., Bertuzzi, M. L., \& Agostini, E. (2010). Toxicity of phenol solutions treated with rapeseed and tomato hairy roots. Desalination, 263(1), 23-28.

Park, J. W., Park, B. K., \& Kim, J. E. (2006). Remediation of soil contaminated with 2,4-dichlorophenol by treatment of minced shepherd's purse roots. Archives of Environmental Contamination and Toxicology, 50(2), 191-195.

Qayyum, H., Maroof, H., \& Yasha, K. (2009). Remediation and treatment of organopollutants mediated by peroxidases: a review. Critical Reviews in Biotechnology, 29(2), 94-119.
Radushev, A. V., Plotnikov, A. V., \& Tyryshkina, V. N. (2008). Regeneration methods of decontamination of phenolcontaining waste waters. Theoretical Foundations of Chemical Engineering, 42(5), 781-794.

Rao, M. A., Scelza, R., Scotti, R., \& Gianfreda, L. (2010). Role of enzymes in the remediation of polluted environments. Journal of Soil Science and Plant Nutrition, 10(3), 333-353.

Regalado, C., Garcia-Almendarez, B., \& Duarte-Vasquez, M. (2004). Biotechnological applications of peroxidases. Phytochemistry Reviews, 3, 243-256.

Sakurai, A., Masuda, M., \& Sakakibara, M. (2003). Effect of surfactants on phenol removal by the method of polymerization and precipitation catalysed by Coprinus cinereus peroxidase. Journal of Chemical Technology and Biotechnology, 78(9), 952-958.

Singh, S., Melo, J. S., Eapen, S., \& D'Souza, S. F. (2006). Phenol removal using Brassica juncea hairy roots: role of inherent peroxidase and $\mathrm{H}_{2} \mathrm{O}_{2}$. Journal of Biotechnology, 123(1), 4349.

Sosa Alderete, L. G., Ibáñez, S. G., Agostini, E., \& Medina, M. I. (2012). Phytoremediation of phenol at pilot scale by tobacco hairy roots. International Journal of Environmental Sciences, 3(1), 398-407.

Suza, W., Harris, R. S., \& Lorence, A. (2008). Hairy roots: from high-value metabolite production to phytoremediation. Electronic Journal of Integrative Biosciences, 3(1), 57-65.

Twiner, M., Dixon, S., \& Trick, C. (2001). Toxic effects of Heterosigma akashiwo do not appear to be mediated by hydrogen peroxide. Limnology and Oceanography, 46(6), 1400-1405.

Varsha, Y. M., Naga Deepthi, C. H., \& Chenna, S. (2011). An emphasis on xenobiotic degradation in environmental clean up. Journal of Bioremediation and Biodegradation, S11, 001.

Wang, T. Y., Wu, Y. H., Jiang, C. Y., \& Liu, Y. (2010). Solid state fermented potato pulp can be used as poultry feed. British Poultry Science, 51(2), 229-234.

Wu, Y., Taylor, K. E., Biswas, N., \& Bewtra, J. K. (1997). Comparison of additives in the removal of phenolic compounds by peroxidase-catalyzed polymerization. Water Research, 31(11), 2699-2704. 